\title{
Refletindo sobre Desafios à Inserção Didática da História e Filosofia da Ciência em Oficina de Formação Docente ${ }^{1}$
}

(Reflecting on Challenges to the Didactical Insertion of History and Philosophy of Science in a Teacher Training Workshop)

\section{WESLEY COSTA DE OLIVEIRA e JULIANA M. HIDALGO F. DRUMMOND}

Universidade Federal do Rio Grande do Norte (wesleyoliveira177@yahoo.com, juliana_hidalgo@yahoo.com)

\begin{abstract}
Resumo. O presente artigo apresenta uma pesquisa empírica realizada em oficina de formação docente. A intervenção realizada buscou a sensibilização quanto à utilização didática de episódios históricos para a abordagem da temática Natureza da Ciência. Entre outros aspectos, foram abordados desafios previstos na inserção didática da História da Ciência e discutidos exemplares de intervenções didáticas. Finalizadas discussões iniciais, os grupos de participantes se engajaram em tentativa de elaborar propostas didáticas a partir de um texto de subsídio sobre a História do Vácuo. A listagem de desafios previstos serviu como referência para a cunhagem de critérios que nortearam a avaliação dessas propostas. A análise qualitativa buscou identificar a possível materialização de desafios, se os participantes tentaram ou não enfrentá-los, dentre outros aspectos. Os resultados podem colaborar para iniciativas de formação docente. Adicionalmente, contribuem com avanços no que diz respeito a referenciais para avaliar a formação de professores visando o uso de abordagens histórico-filosóficas na escola básica.

Abstract. This article presents empirical research conducted in a teacher education workshop. The intervention aimed the awareness of the didactic use of historical episodes to approach Nature of Science. It dealt with expected challenges in didactic transposition of the History of Science and examples of educational proposals. Completed initial discussions, participants were engaged in attempts to develop proposals for the High School taking into account a text on the History of the Void. The list on expected challenges served as reference for coining criteria that guided the evaluation of these proposals. The qualitative analysis tried to identify possible challenges, as well as if the participants tried to confront them or not, among other topics. The results collaborate to teacher training initiatives. Additionally they contribute to advances regarding benchmarks to assess teacher training aimed at using historical and philosophical approaches in basic school.
\end{abstract}

Palavras-chave: história e filosofia da ciência no ensino, natureza da ciência, formação docente

Keyword: history and philosophy of science in teaching, nature of science, teacher training

\section{Considerações iniciais}

Nas últimas décadas, diversos países reformularam e incorporaram perspectivas histórico-filosóficas em seus currículos de ciências (MATTHEWS, 1994; 1995; VANNUCCHI, 1996). Referências nesse sentido são recorrentes na legislação educacional brasileira, a qual preconiza que "o conhecimento físico seja explicitado como um processo histórico, objeto de contínua transformação e associado às outras formas de expressão e produção humanas" (BRASIL, 1999, p. 22).

Argumentos têm sido apontados para a inserção de conteúdos de cunho histórico-filosóficos no ensino. Entre eles figura a concepção de que a História e a

\footnotetext{
${ }^{1}$ Uma versão preliminar deste trabalho foi apresentada no IX ENPEC (OLIVEIRA; FERREIRA, 2013). $\mathrm{O}$ artigo que ora se apresenta constitui um recorte dos resultados da dissertação de mestrado defendida pelo primeiro autor (OLIVEIRA, 2013). Os autores agradecem aos pareceristas pelos comentários e sugestões que contribuíram para a sua versão final.
} 
Filosofia da Ciência (HFC) contribuem para a compreensão da Natureza da Ciência $(\mathrm{NdC}):$ “[...] exemplos da história da ciência são úteis para gerar discussões sobre $\mathrm{NdC}$ e compreender sua natureza contextual" (CLOUGH; OLSON, 2008, p. 144).

Pesquisa recente realizada por Vilas Boas e outros (2013) aponta o fortalecimento da defesa da HFC no que diz respeito à necessidade de levar a temática NdC para a sala de aula. A abordagem desses elementos permitiria a problematização de visões "ingênuas" da ciência e comporia um dos eixos primordiais para a alfabetização científica: "Compreensão da natureza das ciências e dos fatores éticos e políticos que circundam sua prática" (SASSERON et al., 2013, p. 268). De acordo com essa perspectiva, recorrentes publicações vêm sendo observadas (MCCOMAS et al., 1998; HARRES, 1999; GIL PÉREZ et al., 2001; LEDERMAN, 2007; CLOUGH; OLSON, 2008; QUINTAL; GUERRA, 2009; LEDERMAN, 2012; PENA; TEIXEIRA, 2013; SASSERON et al., 2013).

Apesar de significativa argumentação e de sua acolhida por legislações educacionais, a presença de discussões efetivas sobre NdC costuma ser tímida em sala de aula. Por outro lado, visões deformadas sobre a ciência se propagam, ainda que de forma não deliberada: a "postura teórica do professor sobre a natureza da ciência (sua própria epistemologia) pode ser transmitida de forma explícita ou implícita" (MATTHEWS, 1995, p. 187). Pesquisas empíricas vêm diagnosticando visões deformadas que se manifestam justamente por omissão: concepções empíricoindutivistas e ateóricas, algorítmicas, ahistóricas e aproblemáticas, dogmáticas, individualistas e elitistas, exclusivamente analíticas, acumulativas e lineares dos processos de construção da ciência. São transmitidas pela ausência de informações adequadas na fala de professores e nos materiais didáticos (GIL PÉREZ et al., 2001).

Essas dificuldades se devem, em parte, à falta de preparo dos professores, para quem a temática NdC é pouco conhecida (MATTHEWS, 1995; MCCOMAS et al., 1998; HARRES, 1999; LEDERMAN, 2007). Lacunas relacionadas à formação docente tangenciam as barreiras à utilização de episódios históricos tendo em vista a abordagem da NdC. Docentes relatam que os cursos de formação não oferecem subsídios para que sejam capazes de planejar e executar aulas segundo uma perspectiva históricofilosófica. Em parte, esses indivíduos reconhecem lacunas em sua formação. Por outro lado, há aspectos dramáticos dos quais eles não se dão conta: “equívocos a respeito da própria natureza da história da ciência e seu uso na educação" (MARTINS, 2006, p. 
xxvii). Visualizam a HFC como uma introdução ilustrativa, não essencial em sala de aula (MARTINS, 2007).

Face esse contexto, reflexões sobre a HFC na formação docente vêm sendo reforçadas. Afirma-se a importância de que professores participem de discussões, conheçam exemplos de propostas didáticas de cunho histórico-filosófico para a abordagem de conteúdos de ciência e sobre a ciência, desenvolvam competências que lhes permitam adaptá-las, bem como elaborar intervenções apropriadas aos seus contextos (DUARTE, 2004; GATTI et al. 2004; BRINCKMANN; DELIZOICOV, 2009; FERREIRA, 2010; HÖTTECKE; SILVA, 2010; FORATO et al., 2011; 2012; REIS et al., 2014) $)^{2}$.

Partindo dessas considerações, realizou-se oficina de formação docente como atividade de extensão na Universidade Federal do Rio Grande do Norte. A oficina contemplou etapas presenciais que incluíram discussões sobre $\mathrm{NdC}$, exemplos de propostas didáticas para a abordagem da temática por meio de episódios históricos e desafios previstos para a inserção didática da HFC. Após essas etapas, os participantes, em grupos, se engajaram em tentativas de elaboração de propostas didáticas visando abordar a NdC no Ensino Médio (EM). As propostas deveriam ter como base as discussões e o material histórico de referência, elaborado e disponibilizado para leitura em etapa não-presencial prévia à oficina.

O presente artigo apresenta pesquisa empírica de cunho qualitativo que se refere à análise das propostas sugeridas e socializadas pelos participantes. A pesquisa teve como ponto de partida referencial específico para a construção de propostas e materiais para a inserção didática da HFC. Avançou-se de forma a adaptá-lo à formação de professores, como um instrumento para análise de dados. Os resultados decorrentes, obtidos à luz de critérios formulados a partir de referenciais teóricos assinalados, impactaram em desdobramentos para o próprio material histórico elaborado e colaboram como subsídios para intervenções de formação docente. Proporcionam, ainda, avanços no que diz respeito a possibilidades de avaliar a formação de professores visando o uso da HFC na escola básica, sendo esta uma contribuição relevante para a linha de pesquisa. 2 “[...] os materiais devem ser elaborados de modo flexível de forma a permitir que os professores os
adaptem às suas condições atuais e locais" (HÖTTECKE; SILVA, 2010, p. 17). 


\section{Oficina e pesquisa}

Segundo Forato (2009), reflexões sobre os desafios para a inserção didática da História da Ciência ${ }^{3}$ podem colaborar para a elaboração de cursos de formação docente. Isto porque para que a História da Ciência chegue ao contexto educacional, cumprindo as funções que dela se espera, é necessário um processo delicado que demanda conhecimento aprofundado da própria História da Ciência, bem como da Didática da Ciência. Esse processo é pautado, dentre outros fatores, pelo resguardo a uma interpretação diacrônica da ciência. Devem ser evitadas descrições lineares em que cada “descoberta" é encadeada em outra. Pseudo-histórias realçam o papel do personagem "vitorioso" e deixam de lado ideias consideradas "erradas" (PEDUZZI, 2001; MARTINS, 2006; VIDEIRA, 2007; FORATO, 2009; FORATO et al., 2012).

A oficina "Ensinando sobre a Natureza da Ciência: uma abordagem explícita e contextualizada a partir da História do Vácuo" propôs que os participantes refletissem e interagissem criticamente com temas complexos. Por outro lado, a proposta formativa dessa intervenção foi de certa forma limitada, direcionando-se à sensibilização em relação à temática $\mathrm{NdC}$ e à inserção didática da $\mathrm{HFC}$, sobretudo no que diz respeito aos desafios enfrentados nesse processo.

A proposta da oficina teve como ponto de partida pressupostos da historiografia da História da Ciência. Buscou colaborar para "uma leitura mais crítica das versões históricas presentes no Ensino de ciências" (FORATO et al., 2011, p. 36). Distorções da história devem ser rechaçadas tendo em vista as visões de ciência que fomentam. Esse aspecto foi tomado com fundamental, de acordo com a perspectiva de contribuir para a sensibilização dos participantes quanto à temática $\mathrm{NdC}$ e sua importância para a educação científica. Tratando de iniciativas para a inclusão dessa temática, motivou-se a percepção de que a seleção de conteúdos relativos à $\mathrm{NdC}$ demanda reflexão aprofundada acerca de contextos e objetivos educacionais (PUMFREY, 1991; MCCOMAS et al., 1998; GIL PEREZ et al., 2001; LEDERMAN, 2007; FORATO, 2009; FORATO et al., 2011; 2012).

A oficina contou com etapas não presenciais, como resposta, previamente a qualquer outra atividade, a questionário investigativo composto por questões abertas relacionadas à $\mathrm{NdC}$ e à inserção da HFC no ensino. Outra etapa prévia à oficina foi a

\footnotetext{
${ }^{3}$ Ao nos referirmos à História da Ciência, nos remetemos também à Filosofia da Ciência, reconhecendo a relação de interdependência expressa por Lakatos: "A Filosofia da Ciência sem a História da Ciência é vazia; a História da Ciência sem a Filosofia da Ciência é cega” (1998, p.21).
} 
leitura de material de subsídio, intitulado "Uma breve História do Vácuo", elaborado pelos organizadores e disponibilizado para os participantes.

O material de referência para professores foi composto na forma de três narrativas históricas que retomam discussões sobre o vazio na Antiguidade, Idade Média e Revolução Científica ${ }^{4}$. As narrativas utilizam os episódios para a contextualização explícita de aspectos relacionados à $\mathrm{NdC}^{5}$ : o conhecimento científico não é estático e convergente, mas mutável, provisório; a ciência é criativa na invenção de conceitos e explicações; não há um método científico único universal; as observações são dependentes de pressupostos teóricos; o desacordo entre os cientistas sempre é possível; o raciocínio científico não se estabelece sem apelar para fontes sociais, morais, espirituais e culturais (MCCOMAS et al., 1989) ${ }^{6}$.

$\mathrm{Na}$ oficina, uma terceira etapa não presencial consistiu na releitura de material de subsídio buscando a identificação de tentativas de contextualização de aspectos da NdC. Os participantes se engajaram individualmente nessa atividade após a primeira etapa presencial da oficina, que englobou discussões sobre a temática $\mathrm{NdC}$. Ainda no que diz respeito a etapas não-presenciais, posteriormente à oficina, houve resposta individual a questionário investigativo de conteúdo semelhante ao primeiro utilizado ${ }^{7}$. O Quadro 1 destaca as etapas não-presenciais, sintetizando atividades desenvolvidas, duração e material utilizado.

\footnotetext{
${ }^{4}$ As narrativas são detalhadas e extensas, compondo total de 58 páginas. Dentre outras fontes primárias e secundárias, inspiraram os autores a escreverem-nas: MAGIE, 1969; MARTINS, 1989a; 1989b; SOLAZPORTOLÈS; MORENO-CABO, 1997; LONGUINI; NARDI, 2000; PORTELA, 2006. Justifica-se a escolha da História do Vácuo em função da riqueza histórica e alto potencial didático pouco explorado. ${ }^{5}$ A escolha realizada não significa estabelecer um "protocolo do que ensinar". Como Bagdonas e Silva (2013, p. 216) advertem, não há uma visão única adequada sobre a natureza da ciência: a "natureza da ciência é complexa e dinâmica".

${ }^{6}$ As etapas não-presenciais da oficina eram obrigatórias e garantiam a inscrição do participante. Ao realizar a leitura do texto de subsídio, o participante deveria grifar trechos que mencionassem explicitamente aspectos relacionados à $\mathrm{NdC}$, e, em seguida, retornar o arquivo aos organizadores.

${ }^{7}$ O pré-teste, o pós-teste, o material instrucional elaborado como subsídio para professores, bem como as versões escritas das propostas elaboradas pelos grupos estão disponíveis na dissertação da qual o presente artigo advém como recorte (ver OLIVEIRA, 2013).
} 
Quadro 1 - Etapas não presenciais da oficina

\begin{tabular}{|l|l|l|l|}
\hline Atividade desenvolvida & Período & $\begin{array}{l}\text { Duração } \\
\text { estimada }\end{array}$ & Material utilizado \\
\hline $\begin{array}{l}\text { Pré-teste - Temática 1 - } \\
\text { NdC e Temática 2 - HFC } \\
\text { no ensino }\end{array}$ & $\begin{array}{l}\text { Previamente às etapas } \\
\text { presenciais }\end{array}$ & 1 hora & $\begin{array}{l}\text { Questionário aberto, 8 questões } \\
\text { para cada temática }\end{array}$ \\
\hline $\begin{array}{l}\text { Leitura do material de } \\
\text { subsídio }\end{array}$ & $\begin{array}{l}\text { Previamente às etapas } \\
\text { presenciais }\end{array}$ & 2 horas & $\begin{array}{l}\text { Texto "Uma breve história do } \\
\text { Vácuo" }\end{array}$ \\
\hline $\begin{array}{l}\text { Releitura do material de } \\
\text { subsídio para identificação } \\
\text { de aspectos da NdC }\end{array}$ & $\begin{array}{l}\text { Após o primeiro dia de } \\
\text { discussões presenciais }\end{array}$ & 2 horas & $\begin{array}{l}\text { Texto "Uma breve história do } \\
\text { Vácuo" }\end{array}$ \\
\hline $\begin{array}{l}\text { Pós-teste - Temática 1 - } \\
\text { NdC e Temática 2 - HFC } \\
\text { no ensino }\end{array}$ & $\begin{array}{l}\text { Após o segundo dia de } \\
\text { atividades presenciais }\end{array}$ & 1 hora & $\begin{array}{l}\text { Questionário aberto contendo 8 } \\
\text { questões para cada temática }\end{array}$ \\
\hline
\end{tabular}

Fonte: Pesquisa

As etapas presenciais, contempladas em dois dias de oficina, cada um com dois turnos, foram: problematização de questões sobre a $\mathrm{NdC}$ e discussão de visões ingênuas por meio da História do Vácuo; reflexão sobre a inserção da HFC no Ensino e a possibilidade de abordagens explícitas e contextualizadas da $\mathrm{NdC}$; discussão de exemplares de propostas didáticas dessa natureza para o EM; discussão de desafios previstos pela literatura na inserção da HFC no contexto educacional; reflexão sobre a História do Vácuo com referência explícita a conteúdos de $\mathrm{NdC}$; elaboração (orientada) de propostas para abordar a $\mathrm{NdC}$ por meio dos episódios históricos do material de referência; socialização das propostas.

Importante destacar que ao propor a reflexão acerca de desafios previstos na inserção didática da HFC não se tencionava que os participantes os superassem na etapa de elaboração de propostas, o que seria uma pretensão ingênua. Por outro lado, considerando as reflexões ocorridas, tencionou-se que estivessem orientados quanto à importância de refletir sobre os mesmos, sendo essa perspectiva enfatizada durante o processo. O Quadro 2 destaca as etapas presenciais, sintetizando atividades desenvolvidas, duração e material utilizado. 
Quadro 2 - Etapas presenciais da oficina

\begin{tabular}{|l|l|l|l|}
\hline $\begin{array}{l}\text { Atividade } \\
\text { desenvolvida }\end{array}$ & Período & $\begin{array}{l}\text { Duração } \\
\text { estimada }\end{array}$ & Material utilizado \\
\hline $\begin{array}{l}\text { Discussões sobre a } \\
\text { NdC e a HFC no } \\
\text { ensino }\end{array}$ & $\begin{array}{l}\text { Primeiro dia de } \\
\text { atividades presenciais } \\
\text { - manhã }\end{array}$ & 4 horas & Slides de apoio \\
\hline $\begin{array}{l}\text { Discussões sobre a } \\
\text { História do Vácuo e } \\
\text { exemplos de } \\
\text { propostas didáticas }\end{array}$ & $\begin{array}{l}\text { Primeiro dia de } \\
\text { atividades presenciais } \\
\text {-tarde }\end{array}$ & 3 horas & $\begin{array}{l}\text { Slides de apoio } \\
\text { Texto "Uma breve história do } \\
\text { Vácuo" }\end{array}$ \\
\hline $\begin{array}{l}\text { Elaboração de } \\
\text { propostas didáticas }\end{array}$ & $\begin{array}{l}\text { Segundo dia de } \\
\text { atividades } \\
\text { presenciais-manhã }\end{array}$ & 4 horas & Slides de apoio \\
\hline $\begin{array}{l}\text { Socialização das } \\
\text { propostas }\end{array}$ & $\begin{array}{l}\text { Segundo dia de } \\
\text { atividades presenciais } \\
\text { - tarde }\end{array}$ & 3 horas & $\begin{array}{l}\text { Slides e textos elaborados pelos } \\
\text { participantes }\end{array}$ \\
\hline
\end{tabular}

Fonte: Pesquisa

A oficina contemplou vinte indivíduos, licenciandos e professores de Física da Educação Básica. Notaram-se aspectos muito positivos quanto ao interesse dos participantes pelas diversas atividades não-presenciais e presenciais ocorridas na oficina, o que indica a receptividade a esse tipo de intervenção e a necessidade de continuidade dessas iniciativas. Dezoito indivíduos participaram de todas as etapas. Foram considerados participantes da investigação empírica realizada, a qual envolveu dois instrumentos de pesquisa de cunho exploratório (pré e pós-teste), bem como a análise das propostas didáticas elaboradas.

O presente artigo apresenta, especificamente, os resultados da análise das propostas, a qual foi realizada segundo metodologia explicitada na seção subsequente. A análise buscou identificar como desafios previstos se materializaram na elaboração das propostas, se os participantes tentaram ou não enfrentá-los, em que medida foram bem sucedidos em possíveis tentativas, dentre outros aspectos ${ }^{8}$.

\section{Metodologia de análise das propostas}

A análise das propostas foi balizada por desafios sintetizados em referenciais teóricos que tratam da inserção didática da HFC (os quais foram objeto de discussão contextualizada durante a oficina): escolha de mensagens sobre a $\mathrm{NdC}$; seleção de aspectos históricos; nível de aprofundamento dos aspectos históricos e epistemológicos;

\footnotetext{
8 Por restrições de espaço, os resultados do pré e pós-teste não serão discutidos. Além da análise individual das respostas, realizou-se a composição do perfil de cada grupo nessas etapas. Resultados interessantes emergiram da triangulação para cada grupo: análise da proposta didática-perfil pré-testeperfil pós-teste (ver OLIVEIRA, 2013).
} 
nível de detalhamento do contexto não científico; utilização de fontes primárias; adequação da formulação discursiva; consideração de diferenças entre concepções de ciência em distintas épocas; existência de conteúdos históricos que não são de fácil compreensão; tratamento diacrônico de pensadores de épocas e culturas diferentes; criação de atividades pedagógicas com associação de ficção aos episódios (FORATO, 2009; FORATO et al., 2012). A referida listagem foi ampliada e serviu como referência para a elaboração de quatorze critérios (Quadro 3), os quais nortearam as discussões das propostas elaboradas.

Explicitamente, solicitou-se aos participantes que as propostas tivessem a $\mathrm{NdC}$ como preocupação central. Com o primeiro critério, tencionou-se avaliar se os grupos seguiram a recomendação e conseguiram definir o propósito de suas sugestões. No segundo item, observou-se se cada grupo havia definido e expressado os objetivos específicos e se houve coerência com o objetivo geral da proposta. O terceiro critério remonta a aspecto frisado na oficina: estabelecer com clareza que concepções sobre a ciência se deseja ensinar (FORATO, 2009; FORATO et al., 2012). Buscou-se identificar se questões sobre a $\mathrm{NdC}$ foram selecionadas e se seriam abordadas de forma implícita ou explícita, sendo essa última estratégia recomendada pelo favorecimento à sua percepção (ABD-EL-KHALICK; LEDERMAN, 2000; MCCOMAS, 2008; LEDERMAN, 2012). O quarto critério tencionou verificar a consistência entre as escolhas relacionadas à $\mathrm{NdC}$ e os objetivos explicitados.

Quadro 3 - Critérios, identificados por letras, utilizados para avaliação

\begin{tabular}{l}
\hline A) Qual o objetivo geral da proposta? Foi expresso com clareza? \\
\hline $\begin{array}{l}\text { B) Quais os objetivos específicos da proposta? Foram expressos com clareza? Apresentaram } \\
\text { coerência com o objetivo geral? }\end{array}$ \\
\hline $\begin{array}{l}\text { C) Escolheu questões sobre a Natureza da Ciência? Elas apareceram de forma explícita ou implícita } \\
\text { na proposta sugerida? }\end{array}$ \\
\hline D) As questões sobre a Natureza da Ciência escolhidas foram coerentes com os objetivos? \\
\hline $\begin{array}{l}\text { E) Selecionou os aspectos históricos a enfatizar em cada episódio? Eles se relacionam às questões } \\
\text { sobre a NdC selecionadas? }\end{array}$ \\
\hline F) Qual o nível de aprofundamento dos aspectos históricos? \\
\hline G) O contexto não científico foi abordado? Qual o nível de detalhamento? \\
\hline H) Qual o nível de aprofundamento dos aspectos epistemológicos? \\
\hline I) Utilizou trechos de fontes primárias para o aluno? A utilização foi adequada? \\
\hline $\begin{array}{l}\text { J) Apresentou textos e/ou atividades para o aluno? A formulação discursiva estava adequada ao nível } \\
\text { de escolaridade visado? }\end{array}$ \\
\hline L) Levou em consideração diferenças entre concepções de ciência em distintas épocas? \\
\hline $\begin{array}{l}\text { M) Houve dificuldade de tratar diacronicamente pensadores de épocas e culturas diferentes das } \\
\text { nossas? }\end{array}$ \\
\hline $\begin{array}{l}\text { N) Apresentou adequadamente conteúdos da história da ciência que não são de fácil compreensão } \\
\text { para uma pessoa atualmente? }\end{array}$ \\
\hline O) Agregou ficção aos episódios históricos para criar atividades pedagogicamente adequadas? \\
\hline
\end{tabular}

Fonte: Pesquisa 
Os critérios $\mathrm{E}$ e $\mathrm{F}$ se referem à escolha de aspectos históricos e ao nível de aprofundamento dos mesmos. Objetivou-se analisar se foram enfatizados aspectos históricos adequados, tendo em vista a contextualização dos tópicos sobre a $\mathrm{NdC}$ selecionados. As propostas foram também avaliadas quanto ao nível de aprofundamento dos aspectos epistemológicos. Era necessário levar em conta o contexto educacional visado. A inserção de elementos complexos, não usuais, deveria ser criteriosa.

$\mathrm{Na}$ oficina, tratou-se do externalismo como característica considerada pela historiografia da ciência, bem como pela legislação educacional: "O surgimento de teorias físicas mantém uma relação complexa com o contexto social em que ocorreram" (BRASIL, 1999, p. 235). Avaliou-se se, nas propostas, o contexto não científico foi abordado e com que nível de detalhamento. O anacronismo, como tema também abordado na oficina, se materializa entre os desafios à inserção didática da HC e se relaciona aos critérios $\mathrm{L}, \mathrm{M}$ e $\mathrm{N}$.

Outra reflexão importante realizada na oficina diz respeito às fontes primárias. Considerando que o trabalho de interpretá-las é um desafio para os próprios historiadores da ciência ${ }^{9}$, discutiu-se sobre a necessidade de reflexão constante e cautela na inserção de textos históricos originais no ambiente escolar. As propostas foram avaliadas quanto à utilização desse tipo de material. Ainda refletindo aspectos tratados na oficina, completa a lista de critérios a adequação das atividades pedagógicas elaboradas.

\section{Resultados e discussões}

\section{Grupo 1}

O grupo de quatro indivíduos apresentou sua proposta em slides, acompanhados de versão escrita detalhada e de dois textos "elaborados"10 para utilização no EM. Os integrantes apontaram objetivo geral, objetivos específicos e seis atividades. Apresentaram informações sobre duração prevista para atividades e dinâmica de cada uma delas: linha do tempo, discussão do primeiro texto e leitura extraclasse, discussão do segundo texto e leitura extraclasse, discussão acerca da natureza da atividade científica, leitura compartilhada dos textos, construção coletiva de um jornal histórico.

\footnotetext{
9 “Compreender Aristóteles falando sobre a luz e seu sistema de mundo, certamente requereu muitos anos de dedicação dos especialistas" (FORATO, 2009, p. 104).

${ }^{10}$ A explicação para o uso do termo "elaborados" entre aspas seguirá ainda nessa seção.
} 
Os componentes do Grupo 1 explicitaram com clareza o objetivo de ensinar sobre a ciência, ou seja, manifestaram consciência quanto à opção de discutir sobre a natureza da atividade científica. Definiram os objetivos (geral e específicos) de forma articulada e coerente com as orientações, demonstrando-se sensibilizados quanto à relevância da temática NdC para o contexto educacional.

Ao realizar a apresentação inicial da sua proposta didática, o grupo não destacou como objetivo mostrar a ciência como uma atividade humana, influenciada pelo contexto sociocultural. No entanto, demonstrou explicitamente essa preocupação ao apresentar uma sugestão de atividade com o uso de uma linha do tempo, como auxílio à localização temporal dos episódios: “[...] localizar os pensadores no tempo e permitir ao aluno uma compreensão do caráter histórico do desenvolvimento da ciência. [...] construída por diversos povos, no contexto sociocultural de cada época". Esses elementos indicam a intenção de abordar o contexto não científico de forma moderada. O Quadro 4 resume os resultados qualitativos da análise. Trechos em formatação destacada são recortados da versão escrita da proposta.

Quadro 4 - Avaliação da proposta do Grupo 1

\begin{tabular}{|c|c|}
\hline CRITÉRIO & COMENTÁRIO \\
\hline A & $\begin{array}{l}\text { Propósito claramente expresso: "Propiciar a problematização e reflexão sobre } \\
\text { aspectos da Natureza da Ciência utilizando o episódio da História do Vácuo, com } \\
\text { ênfase no confronto entre as ideias de Aristóteles e dos pensadores da Idade Média". }\end{array}$ \\
\hline B & $\begin{array}{l}\text { Objetivos específicos claramente expressos e coerentes com o objetivo geral: "Ao } \\
\text { final desta atividade pretende-se que os alunos tenham refletido sobre os seguintes } \\
\text { questões de NdC: O conflito entre os cientistas é sempre possível, Observações são } \\
\text { influenciadas teoricamente, A ciência tem caráter provisório". }\end{array}$ \\
\hline $\mathrm{C}$ & $\begin{array}{l}\text { Enunciou três aspectos: "O conflito entre os cientistas sempre é possível"; } \\
\text { "Observações são influenciadas teoricamente"; "A ciência tem caráter provisório". } \\
\text { Nos textos "elaborados", os dois primeiros são tratados de forma explícita e o último } \\
\text { de forma implícita. Outros aspectos podem ser percebidos na proposta: O raciocínio } \\
\text { científico não se estabelece sem apelar para fontes sociais, morais, espirituais e } \\
\text { culturais; Os cientistas são criativos na invenção de conceitos e explicações. }\end{array}$ \\
\hline $\mathrm{D}$ & $\begin{array}{l}\text { As três questões acerca da } \mathrm{NdC} \text { enunciadas estão em concordância com os objetivos. } \\
\text { As outras duas mensagens que transparecem não estavam citadas entre os objetivos. }\end{array}$ \\
\hline $\mathrm{E}$ & $\begin{array}{l}\text { Aspectos históricos selecionados: ideias aristotélicas sobre o vácuo e críticas ao } \\
\text { pensamento aristotélico no medievo. Há coerência entre os aspectos históricos e as } \\
\text { questões de NdC selecionadas, embora sejam abordados detalhes históricos que } \\
\text { extrapolam os necessários para discutir essas questões, o que traz complexidade à } \\
\text { proposta. }\end{array}$ \\
\hline $\mathrm{F}$ & $\begin{array}{l}\text { Em vários trechos dos textos "elaborados" são mencionados aspectos históricos } \\
\text { "dispensáveis", se considerados os propósitos pedagógicos. Trechos complexos que } \\
\text { requereriam explicações mais cuidadosas. }\end{array}$ \\
\hline G & $\begin{array}{l}\text { Iniciativa de abordar contexto não científico de forma moderada, em atividade com } \\
\text { linha do tempo para auxiliar na localização temporal dos episódios históricos. }\end{array}$ \\
\hline $\mathrm{H}$ & $\begin{array}{l}\text { Textos "elaborados" referem-se a aspectos epistemológicos, como por exemplo, } \\
\text { hipóteses, evidências empíricas e elaboração de teorias. Possível não familiarização } \\
\text { do estudante em relação a esses aspectos parece não ser levada em conta. }\end{array}$ \\
\hline I & $\begin{array}{l}\text { Textos "elaborados" trazem } 10 \text { trechos longos de fontes primárias, } \\
\text { desacompanhados de explicações e discussões adequadas ao contexto educacional } \\
\text { visado. }\end{array}$ \\
\hline
\end{tabular}




\begin{tabular}{|c|l|}
\hline $\mathrm{J}$ & $\begin{array}{l}\text { Textos “elaborados" poderiam trazer explicações mais claras, na perspectiva de } \\
\text { contribuir para a autonomia do aluno. }\end{array}$ \\
\hline $\mathrm{L}$ & $\begin{array}{l}\text { Não citou objetivo de discutir acerca de concepções de ciência em épocas distintas, } \\
\text { mas não apresentou elementos que desconsiderassem essas diferenças. }\end{array}$ \\
\hline $\mathrm{M}$ & Não apresentou anacronismo. \\
\hline $\mathrm{N}$ & $\begin{array}{l}\text { Os conteúdos históricos necessitariam de seleção mais adequada, tendo em vista os } \\
\text { objetivos e nível de escolaridade visados. }\end{array}$ \\
\hline $\mathrm{O}$ & $\begin{array}{l}\text { Recurso interessante como atividade final em grupo: construção de seções de um } \\
\text { jornal histórico. }\end{array}$ \\
\hline
\end{tabular}

Fonte: Pesquisa

O grupo selecionou três questões sobre a $\mathrm{NdC}$, explicitadas nos objetivos específicos. Ao longo dos textos "elaborados" para os alunos, as duas primeiras questões foram discutidas explicitamente, seguindo orientações da oficina. Já a terceira questão foi abordada de modo exclusivamente implícito, o que poderia acarretar dificuldades quanto à sua percepção. Outras duas questões, além das citadas nos objetivos específicos, transparecem nos textos. Trechos que as contemplam foram realçados pelo grupo, o que indica a intenção de abordá-las e sugere incompletude na redação dos objetivos. Citada esta ressalva, considera-se que ao realizar uma seleção criteriosa de poucos aspectos da $\mathrm{NdC}$, o grupo demonstrou ter clareza quanto à relação intrínseca entre o objetivo pedagógico tencionado e o tempo estimado para possível intervenção ( 8 aulas de 50 minutos cada). Frisou esse aspecto tanto na versão escrita quanto em momentos da apresentação, o que encontra ressonância em recomendações dos referenciais discutidos na oficina (FORATO, 2009).

Demonstrando sensibilização quanto à HFC no Ensino, o grupo explicitou a escolha refletida de episódios históricos. No primeiro texto, foram discutidas as ideias aristotélicas sobre o vácuo, enquanto o segundo trouxe à tona críticas ao pensamento aristotélico acerca do vácuo no medievo. As mensagens de $\mathrm{NdC}$ escolhidas podem, de fato, ser ilustradas pelos aspectos históricos destacados. Porém, os materiais sugeridos incluem diversos aspectos históricos e detalhamentos “desnecessários" "11, se considerados os objetivos expressos pelo grupo. Três das quatro páginas do texto elaborado tratam de detalhes específicos da teoria aristotélica sobre o movimento que extrapolam as discussões sobre o vazio e a pretensão de discutir sobre $\mathrm{NdC}$. Assim, tendo em vista os propósitos pedagógicos e o contexto educacional visado, há complexidade excessiva. Essa característica é significativa tendo em vista a orientação de avaliar criteriosamente o nível de aprofundamento das informações (FORATO,

${ }^{11}$ Esses aspectos históricos poderiam, eventualmente, ser fundamentais no âmbito de outras propostas. 
2009). Nas narrativas, detalhes “desnecessários" contrastam com a ausência de explicações mais claras sobre certos aspectos históricos, potencialmente de difícil compreensão, usados pelo grupo de forma central para contextualizar mensagens de NdC. Argumentos aristotélicos contrários ao vácuo e suas respectivas críticas medievais são exemplos.

Adicionalmente, percebem-se problemas quanto à inserção de fontes primárias nessas narrativas. Foram utilizados dez trechos de fontes primárias ao longo dos dois textos, o que é uma recorrência excessiva, especialmente para o ambiente escolar visado. Considerando a dificuldade de interpretação dos trechos, sua transcrição é pouco recomendável na forma realizada: sem trechos explicativos que suavizem o intrínseco caráter obscuro dos mesmos.

Quanto à adequação da formulação discursiva, houve dificuldade na transposição da $\mathrm{HC}$ dos textos de subsídio ao professor para as narrativas. Há uma composição de recortes literais do texto para o professor, sem reformulação discursiva. Adicionalmente, reflexões de cunho epistemológico não são usuais no ambiente escolar. Os alunos não estariam familiarizados com expressões como "evidências empíricas" e “argumentos racionais", as quais estão presentes nas narrativas propostas. A ausência de elementos elucidativos pode constituir um entrave à autonomia do aluno na leitura. Nesse sentido, a redação apresentada vai de encontro a recomendações de que a autonomia no entendimento das novas expressões se relaciona à aceitação do material didático (FORATO, 2009, p.106).

Acredita-se que seria necessária a reelaboração dos textos visando à adequação dos mesmos. As narrativas, no entanto, não foram o único recurso didático sugerido pelo grupo. Sugeriu-se discutir explicitamente os aspectos de $\mathrm{NdC}$ selecionados em atividades variadas, como debate protagonizado pelos alunos, no qual haveria a contraposição de visões sobre fenômenos explicitados nas narrativas. Tal estratégia poderia contribuir para que viessem à tona eventuais dificuldades de compreensão. Quanto ao uso de ficção para criar atividades pedagógicas, a proposta trouxe um recurso interessante. Trata-se da construção coletiva de jornal histórico, o qual traria matérias sensacionalistas com visões deformadas da ciência ${ }^{12}$.

\footnotetext{
${ }^{12}$ A seguir recorte de proposta de atividade de elaboração de jornal histórico: “O objetivo desta atividade é possibilitar os alunos aplicarem de forma criativa, através da criação de um jornal de época, os conteúdos abordados nas aulas anteriores. Tempo previsto: Duas aulas. Dinâmica da atividade: A turma deverá ser dividida em grupos de 5 pessoas, e cada grupo ficará responsável por desenvolver uma secção do jornal. Sugestões de Seção: (Para cada seção o aluno deverá criar um nome) 1- Matéria de Capa: uma
} 


\section{Grupo 2}

O Grupo 2, composto por quatro indivíduos, apresentou sua proposta projetando texto elaborado pelo grupo, o qual foi impresso e encaminhado aos organizadores da oficina (resultados no Quadro 5).

Quadro 5 - Avaliação da proposta do Grupo 2

\begin{tabular}{|c|c|}
\hline CRITÉRIO & COMENTÁRIOS \\
\hline A & $\begin{array}{l}\text { Objetivo geral da proposta: "promover a reflexão e o debate a respeito do } \\
\text { movimento, utilizando aspectos de natureza da ciência e história da ciência". } \\
\text { Apresentou certa dificuldade ao redigi-lo. Em outros tópicos da proposta, percebeu- } \\
\text { se com mais clareza que o grupo tinha o propósito de ensinar sobre ciência. }\end{array}$ \\
\hline B & $\begin{array}{l}\text { Objetivos específicos apontam a temática NdC: "Ao final desse curso, pretende-se } \\
\text { que os alunos reflitam sobre alguns componentes da visão contemporânea da } \\
\text { natureza da ciência: A natureza não fornece dados suficientemente simples que } \\
\text { permitam interpretações sem ambiguidades; Observações são influenciadas } \\
\text { teoricamente; O desacordo entre os cientistas sempre é possível". }\end{array}$ \\
\hline $\mathrm{C}$ & $\begin{array}{l}\text { Explicitou a escolha de três questões: "A natureza não fornece dados suficientemente } \\
\text { simples que permitam interpretações sem ambiguidades" (implícita), "Observações } \\
\text { são influenciadas teoricamente" (explícita), "O desacordo entre os cientistas sempre } \\
\text { é possível" (explícita). }\end{array}$ \\
\hline $\mathrm{D}$ & Mensagens acerca da NdC em concordância com os objetivos geral e específicos. \\
\hline $\mathrm{E}$ & $\begin{array}{l}\text { Selecionou episódios históricos acerca do vácuo referentes aos pré-socráticos } \\
\text { (eleatas e atomistas). Aspectos históricos enfatizados coerentemente relacionados } \\
\text { com as mensagens de } \mathrm{NdC} \text { selecionadas. }\end{array}$ \\
\hline $\mathrm{F}$ & $\begin{array}{l}\text { Texto elaborado como apoio a alunos do EM abordou aspectos históricos } \\
\text { relacionados às visões dos pré-socráticos quanto à existência ou não do vácuo. A } \\
\text { ausência de explicações claras não contribui para a autonomia do aluno no } \\
\text { entendimento das ideias dos filósofos. Peça teatral a ser encenada pelos alunos (ver } \\
\text { critério O) apontou em direção adequada a objetivos da proposta e público-alvo. }\end{array}$ \\
\hline G & $\begin{array}{l}\text { Não apresentou informações acerca do contexto não científico e não expressou esse } \\
\text { aspecto entre os objetivos. }\end{array}$ \\
\hline $\mathrm{H}$ & $\begin{array}{l}\text { Na referência à cena da peça teatral não foi citada perspectiva de aprofundamento de } \\
\text { aspectos epistemológicos. Já o texto elaborado fez referência a esses aspectos. } \\
\text { Utilizou expressões como "visão teórica" e "evidência empírica". Não transparece } \\
\text { preocupação acerca de tais referências não serem usuais para os alunos. }\end{array}$ \\
\hline $\mathrm{I}$ & Não utilizou fontes primárias. \\
\hline $\mathrm{J}$ & $\begin{array}{l}\text { Texto deveria conter explicações mais claras que contribuíssem para a autonomia } \\
\text { dos alunos no entendimento acerca das discussões sobre NdC, dos conteúdos } \\
\text { históricos e epistemológicos. Cena da peça teatral com formulação discursiva } \\
\text { adequada. }\end{array}$ \\
\hline $\mathrm{L}$ & $\begin{array}{l}\text { Proposta não pretendeu discutir acerca das diferentes concepções de ciência em } \\
\text { épocas distintas, mas não apresentou elementos que desconsiderassem essas } \\
\text { diferenças. }\end{array}$ \\
\hline M & Não apresentou anacronismo. \\
\hline $\mathrm{N}$ & Conteúdos históricos selecionados coerentemente com os objetivos. \\
\hline $\mathrm{O}$ & $\begin{array}{l}\text { Recurso interessante como atividade final: peça teatral. Encenação de debate entre } \\
\text { Leucipo (atomista) e Zenão (eleata) sobre o movimento de uma flecha. }\end{array}$ \\
\hline
\end{tabular}

Fonte: Pesquisa

Grupo 2 explicitou objetivos gerais e específicos, detalhes da proposta, como conteúdos e atividades, cena de peça teatral a ser encenada pelos estudantes do EM e texto de apoio aos mesmos.

reportagem do tipo sensacionalista. Sugestão: Enfatizar concepções inadequadas sobre a NdC; 2- Charge ou história em quadrinhos; 3- Entrevista com os personagens; 4- Fatos Históricos marcantes da época; 5Cultura." 
O grupo parece ter tentado seguir a orientação de ensinar sobre ciência, ainda que tenha demonstrado certa dificuldade ao redigir o objetivo geral da proposta. Já no decorrer da socialização e na versão escrita da proposta, percebeu-se que os objetivos específicos e o texto de apoio aos alunos foram preponderantemente coerentes com essa intenção. Assim, o grupo demonstrou certa sensibilização em relação à temática e à possibilidade de abordá-la por meio da HFC. A opção de contemplar três mensagens sobre a NdC é identificada nos objetivos específicos.

No decorrer do texto de apoio aos alunos, duas mensagens foram abordadas explicitamente e uma implicitamente. Na cena da peça teatral elaborada, essa última opção prevaleceu, o que dificultaria sua percepção. Assim como o Grupo 1, também o Grupo 2 não seguiu à risca as orientações quanto a abordar a temática $\mathrm{NdC}$ de forma preferencialmente explícita (ABD-EL-KHALICK; LEDERMAN, 2000; MCCOMAS, 2008; LEDERMAN, 2012).

No que concerne à coerência entre a escolha de mensagens sobre a atividade científica e os objetivos expressos, o Grupo 2 foi bem-sucedido. Entre os objetivos específicos estavam as reflexões sobre $\mathrm{NdC}$ selecionadas. O grupo escolheu episódios históricos acerca do vácuo relacionados aos pré-socráticos. O recorte histórico priorizou a oposição entre as escolas eleata e atomista quanto à forma de construção do conhecimento, recorrer ou não a evidências sensoriais.

Nessa perspectiva, entende-se que os aspectos históricos enfatizados estavam relacionados com as mensagens de $\mathrm{NdC}$ selecionadas. $\mathrm{O}$ grupo realizou recorte restrito: poucas mensagens de $\mathrm{NdC}$ e conteúdos históricos compatíveis, o que poderia contribuir para uma compreensão "mais adequada" sobre o empreendimento científico. No entanto, considerando o contexto de aplicação visado, os conteúdos selecionados são de difícil compreensão e sua utilização didática deveria ser cercada de cuidados (FORATO, 2009). Considerando que o recorte significou trazer à tona aspectos históricos e epistemológicos complexos, faltaram explicações mais claras.

Não foram exploradas explicações e discussões que poderiam contribuir para a compreensão de termos, expressões e frases não habituais. No tocante à "visão teórica de cada escola", por exemplo, faltaram elementos explicativos, como analogias elucidativas. Ilustra-se a seguir a complexidade das informações expressas:

Nas ideias de pré-socráticos, como Parmênides de Eleia, a rejeição ao mundo observável como irracional e contraditório permaneceu. Para ele, a razão se opunha à sensação, sendo a primeira o caminha único para o conhecimento. $\mathrm{O}$ que de fato existia e podia ser captado pela razão era necessariamente 
imutável. O que vemos e tocamos (sentimos) não passariam apenas de um engano das nossas sensações. As mudanças que observamos em nosso mundo não existiriam, seriam irreais e ilusórias. Não foram os eleatas os únicos a relacionarem vácuo e movimento, Em oposição a parte dessas ideias, os atomistas, entre eles Leucipo e Demócrito, resgatavam a importância do sensorial e concebiam que a construção do conhecimento poderia se dar com auxílio dos sentidos. Eles, também, recorriam a argumentos filosóficos para estabelecer o que era imperceptível sensorialmente.

O texto elaborado pelo grupo não explicou a hermética afirmação de que o mundo observável deveria ser rejeitado como irracional e contraditório. Na ausência de explicação ou contextualização por meio de exemplo, pode-se questionar se o aluno compreenderia o significado dos aspectos históricos e filosóficos enunciados. Expressões como "visão teórica" e "evidência empírica" não foram esclarecidas. A redação poderia ser desmotivante para o aluno, levando-o a rejeitar a leitura (FORATO, 2009, p. 106).

Em contrapartida, avaliou-se que a cena teatral proposta foi elaborada seguindo formulação discursiva adequada. Representou, ainda, uma iniciativa de agregar ficção aos episódios históricos para criar atividade pedagógica interessante, conforme discussões ocorridas durante a oficina ${ }^{13}$. Alunos encenariam um debate fictício entre Leucipo (atomista) e Zenão (Eleata), no qual cada escola iria se referir ao "(suposto) movimento de uma flecha":

Objetivo [da encenação]: Confrontar as ideias de eleatas e atomistas para o caso do movimento de uma flecha, evidenciando os pensamentos de cada escola para essa situação.

ENTREVISTADOR: Estamos aqui hoje com o representante da escola Atomista, Leucipo de Mileto, e um da escola Eleata, Zenão de Elea. Eles vão debater, de acordo com suas visões, sobre o movimento de uma flecha. Para você Leucipo, como se explica o suposto movimento dessa flecha?

LEUCIPO: Na nossa visão Atomista, a flecha entra em movimento porque ela ocupa os espaços vazios que existiam a sua frente, permitindo o seu movimento.

ZENÃO: Eu discordo! Nós Eleatas não acreditamos no movimento porque este movimento é apenas uma ilusão.

ENTREVISTADOR: Leucipo, o que seria então esse vazio que você tanto fala?

LEUCIPO: Este vazio seria a ausência de matéria que é necessário para o movimento.

ZENÃO: Que história é essa! O vazio não existe porque o universo é totalmente cheio. Caso houvesse esse vazio, aí sim, existiria o movimento. Mas como não existe...

LEUCIPO: Negativo. Todo mundo sabe que o universo é formado por átomos e espaços vazios e são justamente esses espaços vazios que permitem o movimento.

\footnotetext{
${ }^{13} \mathrm{Na}$ oficina, os participantes tiveram contato com propostas didáticas e estratégias pedagógicas para a abordagem de conteúdos de NdC por meio da HFC. A utilização de recursos teatrais foi discutida nessa ocasião. Abordou-se a importância de não perder de vista os riscos inerentes à inserção didática da HFC. Nesse caso, situações fictícias precisariam ser avaliadas frente aos riscos da pseudo-história (FORATO, 2009).
} 
Delineou-se, assim, uma possibilidade de explorar o potencial didático do teatro para tratar conteúdos históricos e mensagens de $\mathrm{NdC}$ de forma a contribuir para a compreensão de ambos. Essa poderia ser uma estratégia interessante para discutir explicitamente os aspectos selecionados. Poderia, ainda, trazer à tona eventuais problemas na compreensão dos textos de apoio, colaborando para minimizá-los. Convém destacar, no entanto, a dificuldade de se avaliar a potencialidade da atividade por se tratar de uma única cena. A peça completa não teria sido concretizada por escassez de tempo.

O Grupo 2 não apresentou referência ao contexto não científico ao longo de sua proposta, o que, de fato, não estava listado como objetivo. Não foram notadas, no texto e na cena da peça, interpretações anacrônicas. Não foram utilizadas fontes primárias, sendo essa uma opção possível, discutida na oficina.

\section{Grupo 3}

Composto por quatro indivíduos, o Grupo 3 apresentou esboço de proposta, projetando texto escrito, entregue em versão impressa. A análise sintetizada a seguir sugere a insuficiência das discussões promovidas na oficina para que circunstâncias de compreensão de determinados aspectos fossem alcançadas pelo grupo (ver Quadro 6).

\begin{tabular}{|c|c|}
\hline CRITÉRIO & COMENTÁRIOS \\
\hline A & $\begin{array}{l}\text { Objetivo expresso: "promover a discussão e reflexão a respeito do desenvolvimento } \\
\text { do entendimento sobre o vácuo a partir do experimento de Torricelli". Nesse item } \\
\text { não manifestou intenção explícita de discutir sobre a NdC. }\end{array}$ \\
\hline B & $\begin{array}{l}\text { Objetivos específicos: "Ao término da(s) aula(s) pretende-se que o aluno tenha } \\
\text { analisado os argumentos presenciados na história sobre a existência do vácuo; fazer } \\
\text { com que os alunos entendam a importância dos experimentos para a compreensão e } \\
\text { comprovação teórica; tentar fazer com que os alunos entendam que na ciência existe } \\
\text { a contradição de pensamentos entre cientistas; Promover o estudo da história da } \\
\text { ciência como ferramenta de reflexão de aspectos da natureza". Dificuldade na } \\
\text { redação, inclusive quanto à compreensão sobre o tema NdC. Expressa visões } \\
\text { ingênuas. }\end{array}$ \\
\hline $\mathrm{C}$ & $\begin{array}{l}\text { Expressa intenção de ensinar visão ingênua sobre o experimento e sua relação com a } \\
\text { teoria. Parece tentar escolher aspecto discutido na oficina. Ao redigi-lo como } \\
\text { objetivo demonstra dificuldade: "Tentar fazer com que os alunos entendam que na } \\
\text { ciência existe a contradição de pensamentos entre cientistas". Não foi possível } \\
\text { avaliar se seria abordada explícita ou implicitamente. }\end{array}$ \\
\hline $\mathrm{D}$ & $\begin{array}{l}\text { Redação deficiente quanto à } \mathrm{NdC} \text {, indicação de concepção inadequada entre os } \\
\text { objetivos específicos. }\end{array}$ \\
\hline $\mathrm{E}$ & $\begin{array}{l}\text { Selecionou episódio histórico referente ao experimento do barômetro de mercúrio, } \\
\text { coerente com a intenção de ilustrar a possibilidade de desacordo na ciência. }\end{array}$ \\
\hline $\mathrm{F}$ & $\begin{array}{l}\text { Texto de apoio em fase embrionária, não sendo possível avaliar o nível de } \\
\text { aprofundamento dos aspectos históricos. Não foram apresentadas atividades que } \\
\text { permitissem essa avaliação. }\end{array}$ \\
\hline
\end{tabular}




\begin{tabular}{|c|l|}
\hline $\mathrm{G}$ & $\begin{array}{l}\text { Não apresentou informações acerca do contexto não científico e não expressou esse } \\
\text { aspecto entre os objetivos. }\end{array}$ \\
\hline $\mathrm{H}$ & $\begin{array}{l}\text { Uma única mensagem sobre a NdC, mal redigida, em meio a outros objetivos } \\
\text { específicos que sinalizam visão empirista indutivista. }\end{array}$ \\
\hline $\mathrm{I}$ & Não foi possível avaliar se optaria por utilizar fontes primárias. \\
\hline $\mathrm{J}$ & $\begin{array}{l}\text { Apresenta apenas três perguntas sobre os episódios acerca do experimento de Berti e } \\
\text { do barômetro de mercúrio. Como a proposta estava incompleta, as perguntas ficaram } \\
\text { sem sentido. Não apresenta subsídios aos alunos do EM para as discussões. }\end{array}$ \\
\hline $\mathrm{L}$ & $\begin{array}{l}\text { Não tinha como objetivo discutir acerca de concepções de ciência em ép } \\
\text { distintas, mas não apresentou elementos que desconsiderassem essas diferenças. }\end{array}$ \\
\hline $\mathrm{M}$ & Não apresentou anacronismo. \\
\hline $\mathrm{N}$ & $\begin{array}{l}\text { Não foi possível avaliar a apresentação dos conteúdos históricos, já que não houve } \\
\text { desenvolvimento de textos e/ou atividades pedagógicas para os alunos. }\end{array}$ \\
\hline $\mathrm{O}$ & Não fez referência à utilização de situações fictícias. \\
\hline
\end{tabular}

Fonte: Pesquisa

Ao expressar o objetivo geral, o grupo não manifestou intenção explícita de discutir sobre a NdC. Notou-se certa dificuldade quanto a expressar claramente o que consistiria certa discussão acerca do "desenvolvimento do entendimento sobre o vácuo". Esse esclarecimento seria importante, já que enfoques inadequados podem transmitir concepções ingênuas sobre a ciência (por exemplo, empírico-indutivista e linear; GIL PÉREZ et al., 2001).

As dificuldades do grupo podem ser percebidas também nos objetivos específicos. As referências à $\mathrm{NdC}$ nesse item transitam por visões ingênuas de ciência ou são fragmentadas, sugerindo incompreensão desses conteúdos pelo próprio grupo. $\mathrm{Na}$ redação, "que os alunos entendam a importância dos experimentos para a compreensão e comprovação teórica", há indícios de visões deformadas acerca da ciência. A experimentação seria a essência do empreendimento científico. Não há sinalização acerca da associação intrínseca entre teoria e experimento. Já a redação do objetivo de que os alunos percebam a "contradição de pensamentos entre os cientistas" parece materializar uma compreensão fragmentada da concepção de que "o desacordo entre os pesquisadores é sempre possível", discutida na oficina (MCCOMAS et al., 1998). Considerando que o grupo não descreveu como o objetivo seria atingido, tornase difícil saber se este de fato compreendeu o significado da mensagem que teria procurado enunciar. Ao afirmar o objetivo específico de promover "o estudo da história da ciência como ferramenta de reflexão de aspectos da natureza", o grupo, de modo pouco adequado, aparentemente teria se referido à "Natureza da Ciência" como "natureza".

Na socialização, o grupo não chegou a apresentar uma proposta didática, mas sim esboçou elementos nesse sentido. Afirmou a intenção de elaborar texto de apoio aos 
alunos, o qual não teria sido concluído por insuficiência de tempo. Apresentou três questionamentos sobre os experimentos de Berti e de Torricelli para discussão no EM, mas não indicou como iria discuti-los em coerência com os objetivos pretendidos:

1. Havia entendimento de como a coluna de água se mantinha no tubo do experimento de Berti? 2. Quais os argumentos de Torricelli para acreditar que o vácuo existia? 3. Os filósofos contemporâneos a Torricelli que negavam a existência do vácuo se convenceram da existência dele após o experimento e explicação de Torricelli?

O grupo optou por episódios históricos acerca do experimento do barômetro de mercúrio. A potencialidade desses episódios para discutir acerca da possibilidade de desacordo entre os cientistas é evidente, mas haveria a necessidade de uma abordagem adequada para contextualizar tal aspecto. Tendo em vista o fato de que a proposta foi apresentada em fase embrionária e mesmo suas intenções estavam pouco claras, tornouse inviável avaliar se a abordagem pretendida pelo grupo seria adequada, bem como outros critérios: nível de aprofundamento dos aspectos históricos e epistemológicos, tratamento do contexto não científico, utilização de fontes primárias.

\section{Grupo 4}

$\mathrm{Na}$ etapa de socialização, este grupo de quatro indivíduos exclusivamente apresentou textos históricos "elaborados" para utilização em debate no EM, sem explicar como seria esse tipo de atividade. O grupo utilizou o equipamento "datashow" disponível para projetar os textos desenvolvidos e entregou versão impressa aos organizadores.

Em boa parte, os textos representavam uma transcrição de trechos do material de apoio ao professor, mantinham o nível de aprofundamento, sem adequações necessárias ao contexto educacional. Eram densos, constituídos por numerosos episódios históricos citados de forma detalhada. A definição dos objetivos didáticos não teria sido levada em conta como direcionamento para recortes históricos apropriados (ver Quadro 7).

Pelo que se pôde perceber, em geral, o grupo não manifestou preocupação quanto a abordar conteúdos históricos de difícil compreensão. Em uma única passagem de um dos textos, nota-se a intenção de utilizar certo recurso em prol da compreensão de determinado conteúdo. Em referência à concepção eleata de que as sensações seriam ilusórias, o grupo realizou analogia com a trilogia cinematográfica "Matrix", na qual os personagens se veem em mundo perfeitamente perceptível, porém irreal. A analogia 
seria interessante para o público alvo, se bem discutida e explorada com cuidado em atividade pedagógica.

Não houve indicação de uma proposta efetiva de utilização dos textos, segundo o grupo, por insuficiência de tempo para preparação. É importante considerar, no entanto, que certos elementos, como objetivos didáticos pretendidos, deveriam constituir o ponto de partida para a própria elaboração dos textos. Deveriam ter sido explicitados de forma consciente, ainda que plenamente justificável a não apresentação de uma proposta completa. Face essas lacunas, inferências acerca das possíveis intenções do grupo foram realizadas a partir do material apresentado.

Quadro 7 - Avaliação da proposta do Grupo 4

\begin{tabular}{|c|c|}
\hline CRITÉRIO & COMENTÁRIOS \\
\hline A & $\begin{array}{l}\text { Objetivo geral não expresso. Somente comentou os textos elaborados para alunos do } \\
\text { EM. Infere-se que objetivo seria discutir sobre a NdC por meio da História do } \\
\text { Vácuo. }\end{array}$ \\
\hline B & $\begin{array}{l}\text { Objetivos específicos não citados. Infere-se a intenção de promover a discussão } \\
\text { sobre certos aspectos: o desacordo entre os cientistas sempre é possível; a } \\
\text { observação depende de pressupostos teóricos; o conhecimento científico tem caráter } \\
\text { provisório. }\end{array}$ \\
\hline $\mathrm{C}$ & Teria escolhido mensagens sobre a NdC. Forma implícita. \\
\hline $\mathrm{D}$ & Objetivos não citados. \\
\hline $\mathrm{E}$ & $\begin{array}{l}\text { Textos são resumo que ilustra a maioria dos episódios do material para o professor. } \\
\text { "Seleção" pouco criteriosa. Extrapola relação com as questões sobre } \mathrm{NdC} \\
\text { tencionadas. }\end{array}$ \\
\hline $\mathrm{F}$ & $\begin{array}{l}\text { Complexidade; excesso de informações sobre os episódios históricos, que percorrem } \\
\text { da Antiguidade até a Revolução Científica. }\end{array}$ \\
\hline G & Não há informações acerca do contexto não científico. \\
\hline $\mathrm{H}$ & $\begin{array}{l}\text { Textos tratam implicitamente de aspectos epistemológicos. Utilizam expressões } \\
\text { como "visão teórica" e "evidência empírica", sem explicações apropriadas. }\end{array}$ \\
\hline I & $\begin{array}{l}\text { Textos trazem dez trechos de fontes primárias, alguns bastante longos e complexos. } \\
\text { Não são acompanhados de explicações apropriadas. }\end{array}$ \\
\hline $\mathrm{J}$ & $\begin{array}{l}\text { Textos para o aluno compostos em boa parte por recortes de material para o } \\
\text { professor. Não trazem explicações claras na perspectiva de contribuir para a } \\
\text { autonomia do aluno. Formulação discursiva inadequada. }\end{array}$ \\
\hline $\mathrm{L}$ & Textos não apresentaram elementos que desconsiderassem essas diferenças. \\
\hline M & $\begin{array}{l}\text { Alguns trechos sinalizam aproximação de caráter anacrônico. Julgamento de valor } \\
\text { acerca da concepção cartesiana sobre o vácuo. }\end{array}$ \\
\hline $\mathrm{N}$ & $\begin{array}{l}\text { Necessidade de seleção mais adequada de episódios e cautela em relação a fontes } \\
\text { primárias. Analogia interessante, se bem explorada: trilogia Matrix lembrada ao } \\
\text { tratar da concepção eleata sobre o mundo sensível ser ilusório. }\end{array}$ \\
\hline $\mathrm{O}$ & Não elaborou esse tipo de atividade. \\
\hline
\end{tabular}

Fonte: Pesquisa

A redação das narrativas sugere a seleção de questões discutidas na oficina. Os textos, intitulados “O vácuo não existe!” e “O vácuo existe!”, tratam, respectivamente, de argumentos contrários e argumentos favoráveis à existência do vazio. Registram a construção do conhecimento a partir fundamentos distintos pelas escolas filosóficas. Inclina-se a considerar que uma abordagem implícita de temas da $\mathrm{NdC}$ seria pretendida: 
a possibilidade de desacordo entre pesquisadores e a dependência da observação em relação a pressupostos teóricos (MCCOMAS et al., 1998). Nenhuma alusão explícita à $\mathrm{NdC}$ pode ser notada nos textos, contrapondo-se a uma perspectiva de abordagem explícita e reflexiva sugerida na oficina (ABD-EL-KHALICK; LEDERMAN, 2000; MCCOMAS, 2008; LEDERMAN, 2012). Tal como no caso de materiais elaborados por outros grupos, novamente, expressões como "visão teórica" e "evidência empírica" são apresentadas sem explicações que facilitem sua compreensão.

Na redação dos textos, o grupo transcreveu dez trechos de fontes primárias a partir do material de subsídio. Determinados trechos originais são complexos, de difícil compreensão e não estão nos textos propostos pelo grupo acompanhados de explicações adequadas ao público visado:

\begin{abstract}
De um só caminho nos resta falar: do que é; e neste caminho há indícios de sobra de que o que é, é incriado e indestrutível, porque é completo, inabalável e sem fim. Não foi no passado nem será no futuro, uma vez que é agora, ao mesmo tempo, uno, contínuo; pois que origem lhe poderás encontrar? Como e de onde surgiu? Nem eu te permitirei dizer ou pensar [a partir daquilo que não é] pois não é para ser dito nem pensado o que não é. E que necessidade o teria impelido a surgir se viesse do nada, num momento posterior de preferência a um anterior?
\end{abstract}

A utilização é excessiva e pouco criteriosa, podendo contribuir negativamente quanto aos objetivos pretendidos. O caráter obscuro do trecho citado como exemplo sugere que os alunos do Ensino Médio teriam dificuldade para ler e interpretar as fontes primárias transcritas pelo grupo.

A falta de cautela na utilização desse tipo de material pode contribuir negativamente para o entendimento de aspectos históricos e epistemológicos, bem como pode causar rejeição à própria intervenção didática (FORATO, 2009, p. 104). O grupo mostrou-se, assim, não sensibilizado quanto a aspecto tratado na oficina, sendo desejável que participasse de outras instâncias de discussão sobre o uso didático de fontes primárias.

A oficina havia discutido sobre a atenção necessária à seleção de aspectos históricos e nível de aprofundamento, omissões e simplificações necessárias na inserção didática da HFC. Nesse sentido, é importante destacar que não se esperava que os grupos tivessem sucesso ao enfrentar de forma hercúlea uma tarefa não trivial, tratada da própria oficina como um desafio. No entanto, esperava-se que se mostrassem sensibilizados quanto à existência desse desafio, relatassem sua percepção, problemas e dificuldades, o que não parece ter ocorrido nesse caso. 


\section{Grupo 5}

O grupo de cinco indivíduos utilizou slides para a apresentação de esboço de proposta didática (ver Quadro 8). Trouxe informações sobre o tema escolhido, os objetivos gerais e específicos, o público-alvo e alguns aspectos metodológicos, incluindo detalhes como duração prevista para possível intervenção. Sinalizou a intenção de elaborar dois textos de apoio, o que não teria sido possível por insuficiência de tempo na oficina.

Quadro 8 - Avaliação da proposta do Grupo 5

\begin{tabular}{|c|c|}
\hline CRITÉRIO & COMENTÁRIOS \\
\hline A & $\begin{array}{l}\text { Objetivo geral claramente expresso: "Levar os alunos a refletir sobre alguns aspectos } \\
\text { da construção do conhecimento através da análise dos debates históricos e } \\
\text { desenvolver a capacidade crítica dos mesmos". }\end{array}$ \\
\hline B & $\begin{array}{l}\text { Objetivos específicos expressos, coerentes com o objetivo geral: "Compreender que } \\
\text { linhas de pensamentos divergentes podem permanecer coerentes e racionalmente } \\
\text { válidas; Verificar que a prevalência de uma determinada base filosófica em } \\
\text { detrimento de outra pode ser explicada por uma preferência não neutra; Verificar a } \\
\text { tendência científica/filosófica atualmente prevalente e discutir o porquê dessa } \\
\text { prevalência". }\end{array}$ \\
\hline $\mathrm{C}$ & $\begin{array}{l}\text { Escolheu aspectos sobre a NdC segundo enunciados equivalentes a discutidos na } \\
\text { oficina ("O desacordo entre os cientistas sempre é possível"; "A ciência é uma } \\
\text { atividade não neutra"). Não foi possível avaliar se seriam abordados explícita ou } \\
\text { implicitamente. }\end{array}$ \\
\hline $\mathrm{D}$ & Mensagens em concordância com objetivos geral e específicos. \\
\hline $\mathrm{E}$ & $\begin{array}{l}\text { Selecionou episódios históricos acerca do vácuo referentes a pré-socráticos (eleatas e } \\
\text { atomistas); coerentemente relacionados com as mensagens de } \mathrm{NdC} \text { selecionadas. }\end{array}$ \\
\hline $\mathrm{F}$ & $\begin{array}{l}\text { Não foi possível avaliar o nível de aprofundamento dos aspectos históricos. Não } \\
\text { produziu texto e/ou atividade pedagógica. }\end{array}$ \\
\hline G & $\begin{array}{l}\text { Não apresentou informações acerca do contexto não científico, mas o enfoque } \\
\text { possibilitaria abordagem (terceiro objetivo específico). }\end{array}$ \\
\hline $\mathrm{H}$ & $\begin{array}{l}\text { Apenas explicitou mensagens sobre a NdC selecionadas. Não foi possível avaliar o } \\
\text { nível de aprofundamento dos aspectos epistemológicos. }\end{array}$ \\
\hline $\mathrm{I}$ & Não foi possível avaliar se utilizaria fontes primárias. \\
\hline $\mathrm{J}$ & $\begin{array}{l}\text { Não apresentou subsídios aos alunos para as discussões. Não foi possível avaliar a } \\
\text { formulação discursiva. }\end{array}$ \\
\hline $\mathrm{L}$ & $\begin{array}{l}\text { O enfoque poderia possibilitar essas discussões (terceiro objetivo específico). Não } \\
\text { apresentou elementos que desconsiderassem essas diferenças. }\end{array}$ \\
\hline M & Não apresentou anacronismo. \\
\hline $\mathrm{N}$ & $\begin{array}{l}\text { Não foi possível avaliar a apresentação dos conteúdos históricos. Não produziu } \\
\text { textos e/ou atividades pedagógicas para os alunos. }\end{array}$ \\
\hline $\mathrm{O}$ & Não fez referência à utilização de situações fictícias. \\
\hline
\end{tabular}

Fonte: Pesquisa

No decorrer da análise percebeu-se que o Grupo 5, assim como o Grupo 1, definiu claramente os objetivos (gerais e específicos) de forma articulada e coerente com as orientações da oficina. Esses dois grupos foram os que se demonstraram mais sensibilizados quanto à relevância da temática $\mathrm{NdC}$ para o contexto educacional. 
O Grupo 5 expressou mensagens sobre a $\mathrm{NdC}$ de forma harmoniosa nos objetivos específicos. As mensagens listadas seguem enunciados equivalentes aos discutidos na oficina. A última mensagem selecionada (ver Quadro 8) havia sido discutida, apesar de não ter sido enunciada explicitamente no material de referência para professores. Notou-se certa autonomia do grupo acerca da escolha e da redação das mensagens de $\mathrm{NdC}$, bem como maturidade quanto a estabelecer relações entre os episódios históricos e essas concepções.

Demonstrando certa sensibilização quanto às potencialidades didáticas da HFC, o grupo explicitou a escolha dos episódios históricos. Ainda que não tenha elaborado os dois textos histórico-pedagógicos previstos, manifestou a intenção de discutir no primeiro texto as ideias dos eleatas sobre a inexistência do vazio. O segundo traria à tona os argumentos dos atomistas quanto à existência do vazio. A turma seria dividida em dois grupos. Um deles leria apenas o primeiro texto e outro apenas o segundo texto. A cada grupo seria ministrada uma aula reforçando a perspectiva do texto lido. Cada grupo desconheceria a possibilidade de visão contrária e os argumentos usados para defendê-la até que, em uma terceira aula, a turma fosse reunida para debater sobre o tema “O vácuo existe?".

A proposta seria interessante e, de fato, as mensagens de $\mathrm{NdC}$ escolhidas poderiam ser ilustradas pelos aspectos históricos destacados. Em contrapartida, tendo em vista que a intenções foram apenas esboçadas, não foi possível avaliar se a temática NdC seria abordada de forma explícita ou implícita. Não foi possível avaliar outros critérios como nível de aprofundamento dos episódios, utilização de fontes primárias etc. Faltaram indicações acerca de como se pretendia atingir os objetivos previstos em termos da discussão sobre a ciência.

\section{Considerações finais}

O presente artigo refletiu sobre uma pesquisa empírica realizada em intervenção de formação docente, cuja proposta formativa foi a sensibilização em relação à temática $\mathrm{NdC}$ e à inserção didática da HFC, sobretudo quanto aos desafios enfrentados nesse processo.

A pesquisa realizada à luz de referenciais que tratam da inserção didática da HFC materializou desafios citados nessa literatura (FORATO, 2009; HÖTTECKE; SILVA, 2010; FORATO et al., 2012). Trouxe implicações significativas ao indicar que 
alguns desafios foram observados e superados pelos participantes. Esses aspectos podem ser compreendidos como benefícios formativos. Por outro lado, outros desafios sequer teriam sido notados pelos participantes ${ }^{14}$.

Em geral, os participantes atenderam à orientação de estabelecer a temática $\mathrm{NdC}$ como objetivo geral. Particularmente, dois grupos se destacaram quanto a definir claramente seus objetivos de forma bem articulada e se demonstraram mais sensibilizados quanto à relevância dessa temática. Apenas um grupo demonstrou dificuldade quanto a estabelecer e enunciar a temática $\mathrm{NdC}$ como objetivo. $\mathrm{E}$, de forma aguda, transitou ele próprio por visões deformadas sobre a ciência. Excetuando o referido grupo, identificaram-se resultados positivos entre os demais quanto à seleção de aspectos históricos potencialmente adequados às discussões sobre $\mathrm{NdC}$ selecionadas.

Notaram-se aspectos significativos quanto ao empenho e criatividade dos participantes. Foram citadas sugestões, como a criação de jornal histórico e elaboração de cena teatral, que poderiam resultar em atividades pedagogicamente adequadas. Analogia interessante trouxe à tona filme comercial em colaboração à compreensão de conteúdo histórico complexo.

Demonstrando significativo interesse, os participantes sugeriram ou mesmo chegaram a se empenhar em tentativas de elaboração de materiais didáticos do tipo narrativa histórica ${ }^{15}$. Contudo, nesse processo, dificuldades significativas puderam ser notadas. Os materiais elaborados deixaram transparecer dificuldades convergentes quanto ao nível de aprofundamento dos aspectos históricos e epistemológicos, bem como quanto à formulação discursiva. De maneira geral, podem ser caracterizados como meros recortes de trechos do texto de subsídio ao professor, transcritos sem adequações necessárias. Destaca-se, ainda, o uso ostensivo e pouco criterioso de trechos complexos de fontes primárias, os quais não foram cercados de elementos explicativos. Em certo sentido, os materiais sugeridos para o contexto educacional básico, por serem curtos e ao mesmo tempo englobarem variados episódios históricos, com grau de

\footnotetext{
${ }^{14}$ Esses resultados são complementados por outros, relativos ao pré e pós-teste, os quais podem ser consultados na dissertação de mestrado da qual o presente artigo provém como recorte. Em termos de benefícios formativos para os participantes da oficina destacam-se o amadurecimento de visões ingênuas sobre a NdC, bem como de visões simplistas quanto ao uso da HFC no Ensino (de mera ilustração ou introdução a uma possibilidade de abordagem de conteúdos de $\mathrm{NdC}$ ). Por outro lado, os próprios participantes, em sua maioria, disseram-se ainda inseguros para colocar em prática esse tipo de abordagem.

${ }^{15}$ Segundo estudo recente do tipo "estado da arte", boa parte das propostas didáticas para a inserção da HFC no Ensino tem envolvido esse tipo de suporte (TEIXEIRA et al., 2012). Os participantes não dispunham dessa informação, mas seguiram direção semelhante.
} 
aprofundamento elevado e uso intenso de fontes primárias, revelaram-se de mais difícil compreensão do que o próprio material de leitura para o professor.

Na etapa de socialização, os participantes comentaram sobre a insuficiência de tempo na oficina. Esse é um aspecto significativo, pois um período mais amplo para as reflexões poderia levar à percepção de eventuais dificuldades. Vale salientar, no entanto, que o fator escassez de tempo não foi apontado como justificativa para certas características problemáticas observadas nos materiais elaborados. Ao que tudo indica, os grupos consideraram adequado aquilo que conseguiram produzir. Gostariam de seguir adiante, mas não readequar o que haviam feito.

A análise das propostas, bem como os aspectos vivenciados durante as etapas da oficina evidenciam dificuldades das quais os participantes não se deram conta. Esses resultados trazem à tona elementos significativos que contribuem para o planejamento de intervenções no contexto da formação docente, sobretudo pela identificação de aspectos que precisariam ser tratados de modo intensificado ${ }^{16}$.

À luz desses resultados, desdobramentos têm ocorrido na UFRN em cursos de formação docente que buscam discutir aspectos específicos como, por exemplo, possibilidades e dificuldades na inserção de fontes primárias no contexto educacional ${ }^{17}$.

Adicionalmente, as reflexões decorrentes da investigação realizada, bem como os aspectos vivenciados durante a oficina, ofereceram fundamentos para a elaboração de um texto de orientações para o professor, o qual passou a acompanhar o material "Uma breve História do Vácuo", sendo este acessível ao público interessado em geral (OLIVEIRA, 2013).

O texto de orientações traz discussões sobre desafios na inserção didática da HFC e propostas recentes para superá-los. Essas considerações repercutem aspectos sintetizados na literatura especializada, bem como observações de aspectos críticos na oficina. O texto discute sobre a possibilidade de recorrer a episódios históricos para abordagem da temática $\mathrm{NdC}$ e, a título de exemplo, caracteriza de forma detalhada a narrativa sobre a História do Vácuo e a $\mathrm{NdC}$.

Além de desdobramentos específicos para o material de formação docente proposto, de maneira mais abrangente, a proposta sintetizada no presente trabalho contribui para a linha de pesquisa na qual se insere. Traz resultados relevantes no que

\footnotetext{
${ }^{16}$ Em concordância com Duarte (2004, p. 324), considera-se que: “[...] de nada serve mudar currículos se não houver mudanças nos professores que os implementam".

${ }^{17}$ Iniciativa recente no contexto do Mestrado em Ensino de Ciências Naturais da UFRN foi desenvolvida por Batista (2014).
} 
diz respeito a avaliar a formação docente visando o uso da HFC na escola básica. Tomou-se como ponto de partida referencial para a construção de propostas e materiais, avançando de forma a adaptá-lo para a formação de professores como instrumento para análise de dados. A aplicação desse tipo de instrumento permite reflexões concernentes às necessidades formativas dos professores. Contribuem, portanto, com um contexto de discussões crescentes (DUARTE, 2004; GATTI et al., 2004; BRINCKMANN; DELIZOICOV, 2009; HÖTTECKE; SILVA, 2010; FORATO et al., 2012; REIS et al., 2014).

\section{Referências}

ABD-EL-KHALICK, F.; LEDERMAN, N. The influence of History of Science Courses on Students' Views of Nature of Science. Journal of Research in Science Teaching, v. 37, n.10, p. 1057-1095, 2000.

BAGDONAS, A.; SILVA, C. C. Controvérsias sobre a natureza da ciência na educação científica. In: SILVA, C. C.; PRESTES, M. E. B (Org.). Aprendendo ciência e sobre sua natureza: abordagens históricas e filosóficas. São Carlos: Tipographia, 2013. p. 213-224.

BATISTA, G. L. F. Fontes primárias da história do vácuo e da pressão atmosférica na sala de aula: cartas e jornais históricos em articulação com o livro-texto do ensino médio. Dissertação de Mestrado em Ensino de Ciências e Matemática. Universidade Federal do Rio Grande do Norte, Natal, 2014.

BRASIL, Ministério da Educação. Parâmetros Curriculares Nacionais para o Ensino Médio. Brasília: MEC/SEMTEC, 1999.

BRICCIA, V.; CARVALHO, A. M. P. Visões sobre a Natureza da Ciência construídas a partir do uso de um texto histórico na escola média. Revista Electrónica de Enseñanza de las ciencias, v. 10, n. 1, p.1-22, 2011. Disponível em: $<$ http://reec.uvigo.es/volumenes/volumen10/ART1_Vol10_N1.pdf >. Último acesso em: 17 fev. 2015.

BRINCKMANN, C.; DELIZOICOV, N. C. Formação de professores de Física e a História da Ciência. In: CONGRESSO NACIONAL DE EDUCAÇÃO, 9, 2009, Curitiba. Anais do IX Congresso Nacional de Educação, 2009. Disponível em: < http://www.pucpr.br/eventos/educere/educere2009/anais/pdf/3644_2003.pdf >. Último acesso em: 17 fev. 2015.

CLOUGH, M. P.; OLSON, J. K. Teaching and assessing the nature of science; an introduction. Science \& Education, n. 17, p. 143-145, 2008.

DUARTE, M. C; A história da ciência na prática de professores portugueses: implicações para a formação de professores de ciências. Ciência \& Educação, v. 10, n. 
3, p. 317-331, 2004. Disponível em: <http://www.scielo.br/pdf/ciedu/v10n3/02.pdf>. Último acesso em: 17 fev. 2015.

FERREIRA, J. M. H. Abordando a Natureza da Ciência na formação de professores de física: desafios e perspectivas. In: SILVA, C. C. Silva; PRESTES, M. E. B. (Org.) Aprendendo ciência e sobre sua natureza: abordagens históricas e filosóficas. São Carlos: Tipographia, 2013. p. 245-258.

FORATO, T. C. M. A natureza da ciência como saber escolar: um estudo de caso a partir da história da luz - Tese de Doutorado em Educação. Universidade de São Paulo, São Paulo, 2009.

FORATO, T. C. M.; MARTINS, R. A.; PIETROCOLA, M. Historiografia e Natureza da Ciência na sala de aula. Caderno Brasileiro de Ensino de Física, v. 28, n. 1, p. 27-59, abr. 2011.2 Disponível em: $<$ https://periodicos.ufsc.br/index.php/fisica/article/view/2175-7941.2011v28n1p27 >. Último acesso em: 17 fev. 2015.

FORATO, T. C. M.; MARTINS, R. A.; PIETROCOLA, M. Enfrentando obstáculos na transposição didática da história da ciência para a sala de aula. In: PEDUZZI, L. O. Q.; MARTINS, A. F. P., FERREIRA, J. M. H. (Org.) Temas de história e filosofia da ciência no ensino. Natal: EDUFRN, 2012. p. 123-154.

GATTI, S. R. T; NARDI, R.; SILVA, D. A história da ciência na formação do professor de física: subsídios para um curso sobre o tema atração gravitacional visando às mudanças de postura na ação docente. Ciência \& Educação, v. 10, n. 3, p. 491-500, 2004. Disponível em: < http://www.scielo.br/pdf/ciedu/v10n3/12.pdf >. Último acesso em: 17 fev. 2015.

GIL PÉREZ, D.; MONTORO, I. F.; ALIS, J. C.; CACHAPUZ, A.; PRAIA, J. Para uma imagem não deformada do trabalho científico. Ciência \& Educação, v. 7, n. 2, p. 125153, 2001. Disponível em: < http://www.scielo.br/pdf/ciedu/v7n2/01.pdf >. Último acesso em: 17 fev. 2015.

HARRES, J. B. S. Uma revisão de pesquisas nas concepções de professores sobre a natureza da ciência e suas implicações para o ensino. Investigações em Ensino de Ciências, v. 4, n. 3, p. 197-211, 1999. Disponível em: <http://www.if.ufrgs.br/ienci/artigos/Artigo_ID53/v4_n3_a1999.pdf>. Último acesso em: 17 fev. 2015.

HÖTTECKE, D.; SILVA, C. C. Why Implementing History and Philosophy in School Science Education is a Challenge: An Analysis of Obstacles. Science \& Education, v. 20, p. 293-316, 2010.

LAKATOS, I. História da ciência e suas reconstruções racionais. Lisboa: Edições 70, 1998.

LEDERMAN, N. G. Nature of science: past, present and future. In: ABELL, S.K.; LEDERMAN, N. G. (Org.), Handbook of Research on Science Education. Mahwah, New Jersey: Lawrence Erlbaum Publishers, 2007. p. 831-880. 
LEDERMAN, N. G. Nature of scientific knowledge and scientific inquiry: building instructional capacity through professional development. In: FRASER, B. J.; TOBIN, K. J.; MCROBBIE, C. Second International Handbook of Science Education. v. 1. Dordrecht, London: Springer, 2012. p. $335-360$.

LONGUINI, M. D.; NARDI, R. Origens históricas e considerações acerca do conceito de pressão atmosférica. Caderno Brasileiro de Ensino de Física, v. 19, n.1, p.67-78, abr. 2002. Disponível em: <https://periodicos.ufsc.br/index.php/fisica/article/view/9295 >. Último acesso em: 17 fev. 2015.

MAGIE, W. F. A source book in Physics. Cambridge, MA: Harvard University Press, 1969.

MARTINS, A. F. P. História e filosofia da ciência no ensino: Há muitas pedras nesse caminho. Caderno Brasileiro de Ensino de Física, v. 24, n.1, p.112-131, abr. 2007.

Disponível em: < https://periodicos.ufsc.br/index.php/fisica/article/view/6056 > Último acesso em: 17 fev. 2015.

MARTINS, R. de A. O vácuo e a pressão atmosférica, da Antiguidade a Pascal. Cadernos de História e Filosofia da Ciência, v. 1, n. 3, p. 9-48, 1989a.

MARTINS, R. de A. Tratados Físicos de Blaise Pascal. Cadernos de História e Filosofia da Ciência, Série 2, 1 (n. esp.), p. 49-165, jan./dez. 1989b.

MARTINS, R. de A. Introdução: A história das ciências e seus usos na educação. In: SILVA, C. C. Estudos de história e filosofia das ciências: subsídios para aplicação no ensino. São Paulo: Livraria da Física, 2006. p. xxi-xxiv.

MATTHEWS, M. R. Science teaching: the role of History and Philosophy of Science. New York, London: Routledge, 1994.

MATTHEWS, M. R. História, Filosofia e Ensino de Ciências: a tendência atual de reaproximação. Caderno Catarinense de Ensino de Física, v. 12, n. 3, p. 164-214, dez.1995.

Disponível em: < https://periodicos.ufsc.br/index.php/fisica/article/view/7084 > Último acesso em: 17 fev. 2015.

MCCOMAS, W. F., AlMAZROA, H.; CLOUGH, M. The Nature of Science in Science Education: An introduction. Science \& Education, n. 7, p. 511-532, 1998.

OLIVEIRA, W. C. de. Ensinando sobre a Natureza da Ciência: uma abordagem explícita e contextualizada a partir da História do Vácuo - Dissertação de Mestrado em Ensino de Ciências e Matemática. Universidade Federal do Rio Grande do Norte, Natal, 2013.

OLIVEIRA, W. C. de.; FERREIRA, J. M. H. Investigando obstáculos à transposição didática da HFC em oficina de formação docente. In: ENCONTRO NACIONAL DE PESQUISA EM EDUCAÇÃO EM CIÊNCIAS, 9, 2013, Águas de Lindóia, SP. Anais do IX ENPEC. ABRAPEC. 2013. Disponível em: 
$<$ http://www.nutes.ufrj.br/abrapec/ixenpec/atas/resumos/R1457-1.pdf>. Último acesso em: 22 fev. 2015.

PEDUZZI, L. O. Q. Sobre a utilização didática da História da Ciência. In: PIETROCOLA, M. Ensino de física: conteúdo e epistemologia numa concepção integradora. Florianópolis: Ed. da UFSC, 2001. p. 151-170.

PENA, F. L. A., TEIXEIRA, E. S. Parâmetros para avaliar a produção literária em História e Filosofia da Ciência voltada para o ensino e divulgação das ideias da Física. Caderno Brasileiro de Ensino de Física, v. 30, n. 3, p. 471-491, 2013.

Disponível em: <https://periodicos.ufsc.br/index.php/fisica/article/view/21757941.2013v30n3p471>. Último acesso em: 17 fev. 2015.

PORTELA, S. I. C. O Uso de Casos Históricos no Ensino de Física: Um Exemplo em Torno da Temática do Horror da Natureza ao Vácuo. Dissertação de Mestrado em Ensino de Ciências. Universidade de Brasília, Brasília, 2006.

PUMFREY, S. History of science in the National Science Curriculum: A critical review of resources and their aims. British Journal of History of Science, n. 24, p. 61-78, 1991.

QUINTAL, J. R.; GUERRA, A. A História da Ciência no Processo Ensinoaprendizagem. Física na Escola, v. 10, n. 1, p. 21-25, 2009.

Disponível em: <http://www.sbfisica.org.br/fne/Vol10/Num1/a04.pdf>. Último acesso em: 17 fev. 2015.

REIS, J. C.; GUERRA, A.; BRAGA, M. Da importância da História e Filosofia da Ciência na Formação de Professores. In: GOMES, M. de F. T.; BARRETO, T. de A. Pesquisas e Vivências em Formação de Professores. Rio de Janeiro: Letra Capital. 2013. p. 13-24.

SOLAZ-PORTOLÈS, J. J.; MORENO-CABO, M. El espacio vacío y sus implicaciones en la historia de la ciencia. Caderno Brasileiro de Ensino de Física, v. 14, n. 2, p. 194208, ago.1997. Disponível em: $<$ https://periodicos.ufsc.br/index.php/fisica/article/view/7033 >. Último acesso em: 17 fev. 2015.

TEIXEIRA, E. S.; GRECA, I. M.; FREIRE JR, O. Uma revisão sistemática das pesquisas publicadas no Brasil sobre o uso didático de história e filosofia da ciência no ensino de física. In: PEDUZZI, L. O. Q.; MARTINS, A. F. P., FERREIRA, J. M. H. (Org.) Temas de história e filosofia da ciência no ensino. Natal: EDUFRN, 2012. cap. 1, p. 9-40.

VANNUCCHI, 1996. História e filosofia da Ciência: da teoria para a sala de aula. Dissertação de Mestrado em Ensino de Ciências - Universidade de São Paulo, São Paulo, 1996.

VIDEIRA, A. A. P. Historiografia e história da ciência. Escritos, v. 1, p. 111-158, 2007. Disponível em: <http://www.casaruibarbosa.gov.br/escritos/numero01/FCRB_Escritos_1_6_Antonio_A ugusto_Passos_Videira.pdf >. Último acesso em: 17 fev. 2015. 
VITAL, A.; GUERRA, A. A natureza da ciência no ensino de física: estratégias didáticas elaboradas por professores egressos do mestrado profissional. Caderno Brasileiro de Ensino de Física, v. 31, n.2, p. 225-257, ago. 2014. Disponível em: < https://periodicos.ufsc.br/index.php/fisica/article/viewFile/2175-

7941.2014v31n2p225/27317>. Último acesso em: 17 fev. 2015.

WESLEY COSTA DE OLIVEIRA. É licenciado em Física pelo Instituto Federal de Educação, Ciência e Tecnologia do Rio Grande do Norte (2006) e mestre em Ensino de Ciências pelo Programa de Pós-Graduação em Ensino de Ciências Naturais e Matemática da Universidade Federal do Rio Grande do Norte. Atua como professor do ensino médio na rede pública de Natal e exerce a função de técnico de laboratório de física na Escola de Ciências e Tecnologia da UFRN. É supervisor do subprojeto Física do Programa Institucional de Bolsa de Iniciação à Docência (PIBID) na UFRN e doutorando do Programa de Pós-Graduação em Ensino de Ciências e Matemática.

JULIANA M. HIDALGO F. DRUMMOND. É bacharel em Física pela Universidade Estadual de Campinas, mestre em Historia da Ciência e doutora em Filosofia/ Filosofia da Ciência pela Pontifícia Universidade Católica de São Paulo. Realizou estágios de pós-doutoramento na UNICAMP e na PUC-SP. Desde 2008 é professora pesquisadora no Departamento de Física Teórica e Experimental da Universidade Federal do Rio Grande do Norte. Atua como docente orientadora no Programa de Pós-Graduação em Ensino de Ciências Naturais e Matemática da UFRN. Foi coordenadora do subprojeto PIBID-Física na UFRN. Atua nas áreas de História da Ciência, História e Filosofia da Ciência no Ensino e Natureza da Ciência.

Recebido: 18 de fevereiro de 2015

Revisado: 09 de junho de 2015

Aceito: 02 de julho de 2015 